\title{
Development of Growth Models Based on Years for Salep Orchid Planted in Natural Environment
}

\author{
Dursun Kurt ${ }^{*}$ \\ https://orcid.org/0000-0001-6697-3954
}

${ }^{1}$ University of Ondokuz Mayis, Vocational School of Bafra, Department of Plant and Animal Production, Samsun, Turkey.

Received: 2019.12.23; Accepted: 2020.06.10.

*Correspondence: dursun.kurt@omu.edu.tr; Tel.: +90-362-5426762

HIGHLIGHTS

- Findings are first data for Dactylorhiza euxina (Nevski) Czerep orchids.

- The main tuber completes its life by producing a slightly larger new tuber.

- It takes 4-5 years for a germinated $D$. euxina seed to reach a sufficient size.

- These data make it easier for us to predict the development of other salep orchids.

\begin{abstract}
The orchids that produced tuber are known as salep orchids and have been collected from nature for centuries as a medicinal and aromatic plant. These orchids are endangered species because of their limited vegetative and generative production possibilities. Salep orchids, seed germination has been achieved with in-vitro studies, but no source has been found regarding the development of germinated seeds over the years. In this study, Dactylorhiza euxina (Nevski) Czerep. was used as research material. Seeds that were determined to germinate in nature were observed to develop in their own environment for five years and some morphological characteristics (plant height, number of leaves, leaf length, leaf width, total weight, tuber width, and tuber weight) were determined at the end of each vegetation year. Plants that start to develop with seed germination produce one leaf and a tuber of $0.115 \mathrm{~g}$ in the first year. When the tubers obtained from the first year were planted again, the plants was obtained 2-3 leaves and they were formed 0.465 grams of tubers. In the third year plants bloom for the first time. The period until flowering in the plant was called maturity period and Dactylorhiza euxina (Nevski) Czerep. was found to have a 3-year maturity period. Plants produced tuber $0.850 \mathrm{~g}$ in the third year, $1.585 \mathrm{~g}$ in the fourth year and $2.522 \mathrm{~g}$ in the fifth year. According to the mathematical modeling, the relationship between year $(Y)$ and fresh tuber weight (FTW) was found $Y=$ $1.22+(1.61 \times \mathrm{FTW})$ and there was a significant relationship among year, fresh tuber weight, and total biomass $($ TBM $)$. This equation $Y=1.05+(0.76 \times \mathrm{FTW})+(0.14 \times \mathrm{TBM})$ shows us the mathematical relations of year, fresh tuber weight, and total biomass. The mathematical relations among to fresh tuber weight, total biomass, and plant height $(\mathrm{PH})$ was produced $\mathrm{Y}=1.74-(0.11 \times \mathrm{FTW})+(0.57 \times \mathrm{TBM})-(0.09 \times \mathrm{PH}) . \mathrm{R}^{2}$ values were found $0.95-0.99$. All $R^{2}$ values and standard errors were found to be significant at the $p<0.01$ level.
\end{abstract}

Keywords: biomass; Dactylorhiza euxina (Nevski) Czerep.; maturity period; model; salep; terrestrial; tuber. 


\section{INTRODUCTION}

Orchidaceae family is the second largest species in the world with $25000-30000$ species and this number is increasing with newly found and hybrid species [1,2]. Within the Orchidaceae family, the named terrestrial orchids, which produce tubers under the ground, are known as salep orchids. Salep flour is obtained from the tubers of salep orchids and it has been used as a medicinal plant for centuries [3,4]. Today, it is mostly consumed in Maras ice cream making and as hot drink [5-8].

The genus Dactylorhiza has different characteristics in the Orchidaceae family. All other orchids produce oval shaped tubers while Dactylorhiza genus produces finger shaped tubers. The wide adaptability of this species is seen at altitudes between $0-2000 \mathrm{~m}$ and it is reported to spread from Europe, Mediterranean, North Africa to Asia [9-14]. Another difference from other species is that it has high glucomannan content. It is a more valuable orchid genus with this feature [15-17]. Dactylorhiza euxina (Nevski) Czerep., which is selected as research material, is also an important species of salep orchid which is common in mild climatic conditions and forms a finger shaped tuber.

In the flowers of orchids, ovarium which is developed after fertilization forms the fruit in capsule shape. It contains thousands of seeds. The common feature of all orchids is that they all have seeds at the microscopic size. The most important feature that distinguishes orchids from other seed plants is the absence of endosperm in orchid seed and embryos of seeds also consist of relatively few cells (40-50 units). Another noteworthy issue in the seed structure is that the parts that will form the plant parts such as roots, stems and shoots after germination are not shaped. This condition is called morphological dormancy [18-20.]

An adult salep orchid can produce at least 8-10 seed capsules and tens of thousands of seeds in these capsules. However, it is impossible for seeds of microscopic size and lack of endosperm to germinate by themselves. In the germination stage, the seeds must receive support from a different living organism [2124]. Therefore, one millionth of orchid seeds have a chance to germinate. Germination of seeds is very slow and lasts for many years. The period for germination and planting of embryos of the orchid plant, which is quite different from other plants in biological conditions, varies from species to species. Germinated seedling completes the first year with one or two small leaves. In the following years, the growth of plants continues and they acquire the ability to form flowers.

Seed from germination to flowering period can be called the period of maturity. Because only plants that can reach generative maturity can produce flowers and produce seeds. The duration of this period depends on the genetic characteristics of the species. Nevertheless, germination of the seeds in tissue culture environment and the development of plants from the protocorm formed in the continuation have been achieved worldwide but the developmental processes of the obtained seedlings have not been followed. There is not enough information about this subject [15-25].

In vitro studies with tissue culture are mostly limited to species-based germination studies. In this study, the findings of some researchers who make observations in nature are included. Seed production in salep orchids in the study of Tutar and coauthors [26] stated that germinated seeds can reach flowering size after 3-4 years. Sezik [25] also reported that leaves and tubers from germinated seeds occurred after many years and the average shortest period is 2-4 years. However, there are insufficient sources as to which type of salep orchid has completed its maturity.

In this study, Dactylorhiza euxina (Nevski) Czerep. species orchids, which were found to germinate in their natural environment during field trips, were taken under protection. The growth of the plants in their own environment for five years. In addition, the mathematical models were developed to estimate how old the tubers or tuberous seedlings.

\section{MATERIAL AND METHODS}

Dactylorhiza euxina (Nevski) Czerep. species were found especially on 800 meters altitude and streamside during the field trips conducted to determine the diversity of orchids in Samsun province. The species, which is a study material, is located in the Daldere region of Ladik district. In the region where the species is spread, new sprouts appear to have grown from seed around the adult plants. Sample shoots have been marked in order to follow the development of these new plants over the years and reveal the maturity period for many years. In the area where the test material is detected, three fresh germinated plants are shown in Figure 1 to identify the material.

In the research area, 30 plantlets were identified. These sprouts, which are the test material, were separated from the adult individuals and brought together with their own soil in the same area and planted. It was understood that these new sprouts formed roots and tubers after six months (Figure 1c-d-e). In the 
first year of orchid germination, a tiny tuber is produced. This tiny tuber completes the growing season in the next vegetation year, producing a new tuber larger than itself. This process continues until the new tuber reaches a certain size. The old tuber rots and disappears at the end of vegetation [15]. In this study, five vegetation years were examined and the following observations were taken at the end of each vegetation year. The plants were illustrated in order to summarize the annual growth of seedlings.

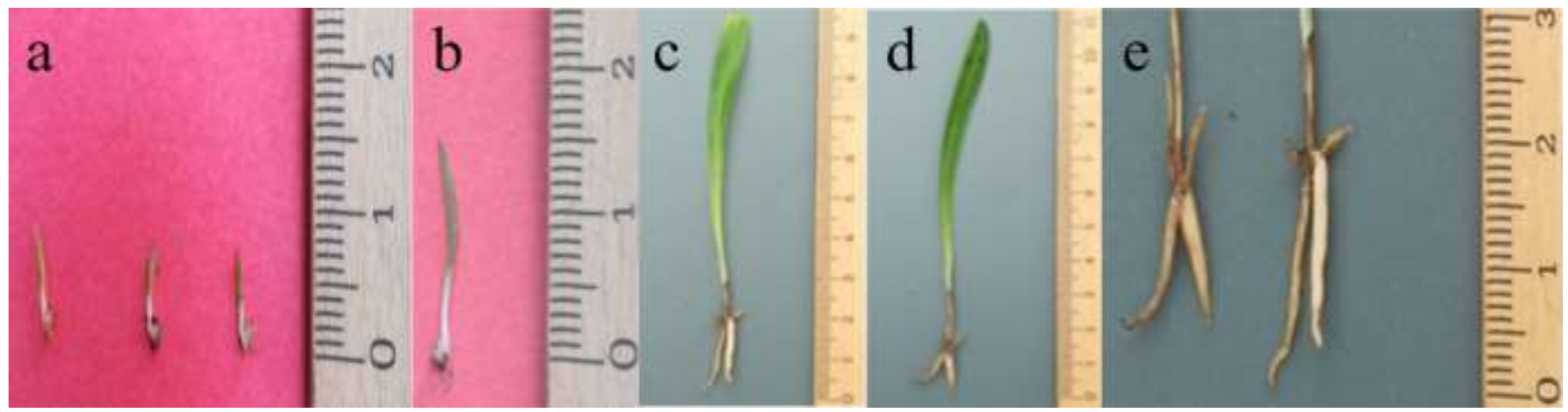

Figure 1. $\mathbf{a}-\mathbf{b}$ : First stage of germination seed development (Leaf development started but no root development) and first root of orchid sprout after germination. $\mathbf{c}-\mathbf{d}-\mathbf{e}$ : Sample plantlets corresponding to the size of tuber formation (in the first year plants consist of 3 root extensions and a tiny tuber).

\section{Morphological measurements}

Plant height: The length of the shoot up to the top flower. Since the plants did not produce flowers for the first two years, only leaf sizes were taken.

Number of leaves: The number of leaves found in a single plant. The development of the petiole is included in the number of small leaves on the petiole.

Leaf length: The longest of the leaves in the plant was taken as the observation value

Leaf width: The width of the largest leaf of the plant was taken as observation values.

Total weight: The fresh weight of all biomass below and below the soil samples removed from the soil.

Tuber width: The distance between the two sides of the tuber.

Tuber weight: Average fresh weight of tubers taken from samples.

\section{Statistical analysis}

The data obtained from the research were analyzed according to randomized plots design using JMP 13 statistical software, and averages were interpreted with Tukey's multiple comparison test. It is very important to know what vegetation period the plant materials in the field are in, to use the material correctly, to plan the study correctly and to understand the life stages of salep species. For this purpose, mathematical models were developed to estimate how old the tubers or tuberous seedlings were. The mathematical models (equation) were symbolized $Y=a+\left(b \times X_{1}\right)+\left(c \times X_{2}\right)+\left(d \times X_{3}\right)$. In this equation, $a, b, c$, and $d$ are coefficiencies. $Y$ (year) is dependent variable. $X 1$ (fresh tuber weight), $X_{2}$ (total biomass), and $X_{3}$ (plant height) are independent variables. Regression analysis and curve fitting were performed with MATLAB software. Curve fitting processes were continued until the least sum of square of residuals was obtained.

\section{RESULTS AND DISCUSSION}

As with all orchids, orchids have to be fed with the help of another living group from the outside during the first stage of their life. Fungi from the group of mycorrhiza, which help germinate the seeds of the orchids and provide the necessary nutrients. Salep orchid seeds enter into common life with fungi in the first developmental period. Mycorrhizal fungi feed the orchid seeds from the organic residues in the soil and feed them and help them grow. This relationship between mycorrhizal fungus and seed is called symbiotic life $[21,23,27-29]$. When examined carefully in Figure $1 a-b$, a germination and shoot emergence occurred in the leaves and individuals that form the root system is not seen. This is a good example proving that the seed is fed by fungi. As with other orchid species, after the germination of Dactylorhiza euxina (Nevski) Czerep. orchid seeds, the developmental processes continue for many years. No sources of annual growth and flowering were found. In this study carried out in order to eliminate the lack of information, individuals who have germinated in their natural environment were used. In the developmental period followed for four years, 
in addition to the obtained morphological features, sample individuals were illustrated at the end of each vegetation (Figure 2).

When the plants start to fade, it is understood that their development stops and necessary measurements are made at this stage. The obtained morphological features and their results of statistical analysis are shown in Table 1.

In the 30 plants used as materials, only one tuber development occurred in the first year (Figure 2). Average leaf width is $1.1 \mathrm{~cm}$ and leaf length is $9.3 \mathrm{~cm}$. produced in the first year of the tuber's fresh weight is only $0.115 \mathrm{~g}$. In the first year of germination, total biomass weight including root, tuber and upper parts was measured as 0.34 grams.

Table 1. Some morphological features of the four-year development process.

\begin{tabular}{lccccccc}
\hline Years & $\begin{array}{c}\text { Leaf number } \\
\text { per plant }\end{array}$ & $\begin{array}{c}\text { Leaf length } \\
(\mathrm{cm})\end{array}$ & $\begin{array}{c}\text { Leaf width } \\
(\mathrm{cm})\end{array}$ & $\begin{array}{c}\text { Total biomass } \\
(\mathrm{g})\end{array}$ & $\begin{array}{c}\text { Fresh tuber } \\
\text { weight }(\mathrm{g})\end{array}$ & $\begin{array}{c}\text { Tuber width } \\
(\mathrm{mm})\end{array}$ & $\begin{array}{c}\text { Plant height } \\
(\mathrm{cm})\end{array}$ \\
\hline $1^{\text {st }}$ year & $1.0 \mathrm{c}$ & $9.3 \mathrm{c}$ & $1.1 \mathrm{~d}$ & $0.34 \mathrm{e}$ & $0.115 \mathrm{e}$ & $0.46 \mathrm{e}$ & - \\
$2^{\text {nd }}$ year & $2.5 \mathrm{bc}$ & $13.3 \mathrm{ab}$ & $2.3 \mathrm{c}$ & $2.63 \mathrm{~d}$ & $0.465 \mathrm{~d}$ & $0.93 \mathrm{~d}$ & - \\
$3^{\text {rd }}$ year & $4.0 \mathrm{ab}$ & $13.2 \mathrm{~b}$ & $2.7 \mathrm{~b}$ & $9.02 \mathrm{c}$ & $0.850 \mathrm{c}$ & $1.33 \mathrm{c}$ & 41.7 \\
$4^{\text {th }}$ year & $5.0 \mathrm{a}$ & $13.8 \mathrm{a}$ & $2.8 \mathrm{~b}$ & $12.41 \mathrm{~b}$ & $1.585 \mathrm{~b}$ & $1.41 \mathrm{~b}$ & 48.8 \\
$5^{\text {th }}$ year & $5.0 \mathrm{a}$ & $13.5 \mathrm{ab}$ & $3.3 \mathrm{a}$ & $14.32 \mathrm{a}$ & $2.522 \mathrm{a}$ & $2.50 \mathrm{a}$ & 50.1 \\
\hline \multicolumn{7}{c}{ Mean squares and significance } \\
\hline Years & $36.0^{* *}$ & $41.9^{* *}$ & $8.3^{* *}$ & $441.8^{* *}$ & $11.1^{* *}$ & $6.9^{* *}$ & $\mathrm{Q}(\mathrm{a}=0.05)$ \\
\hline
\end{tabular}

${ }^{\star *}$; All examined features are significant at the level of $p<0.01$.

In the second year, during the vegetation period some of the plants produced two leaves and some of them produced three leaves. The average weight of tubers at the end of the second vegetation year was $0.465 \mathrm{~g}$. Plant height values could not be obtained in the first two years. Because, in these years, there are no above-ground parts other than leaves. Total biomass weight average was 2.63 grams in the second year.

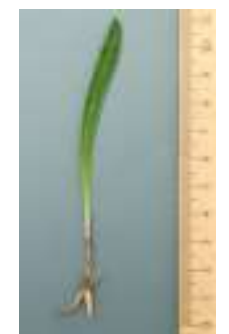

First year 25 June 2015

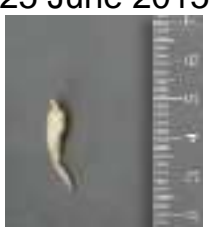

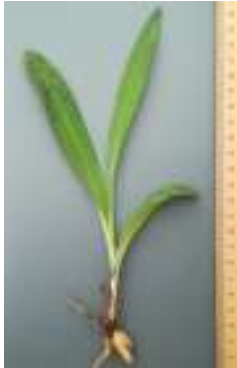

Second year 28 June 2016

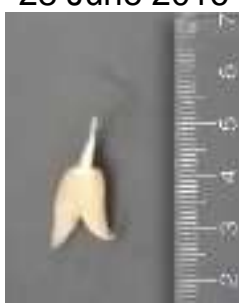

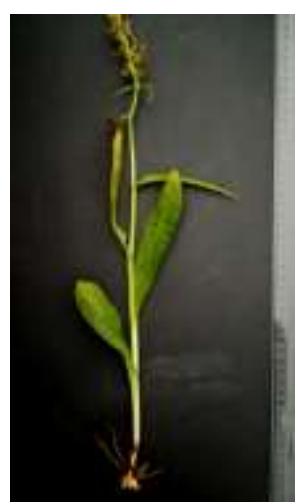

Third year

25 June 2017

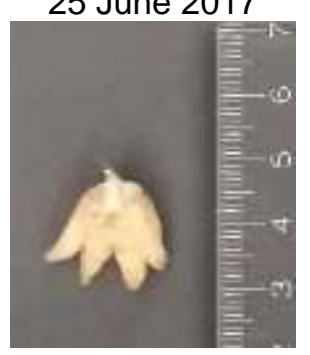

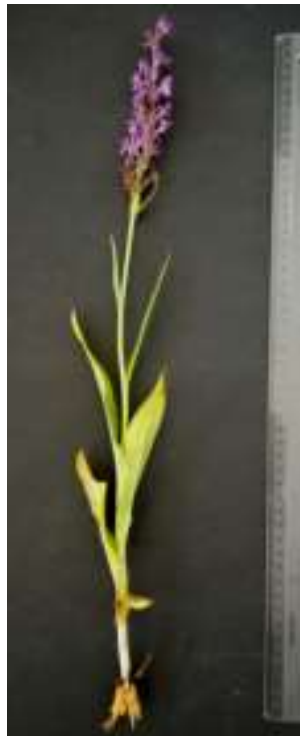

Fourth year

24 June 2018

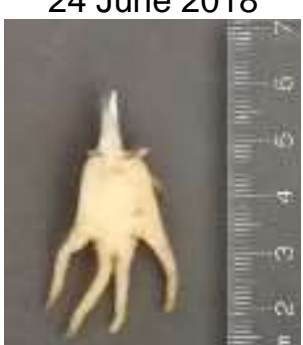

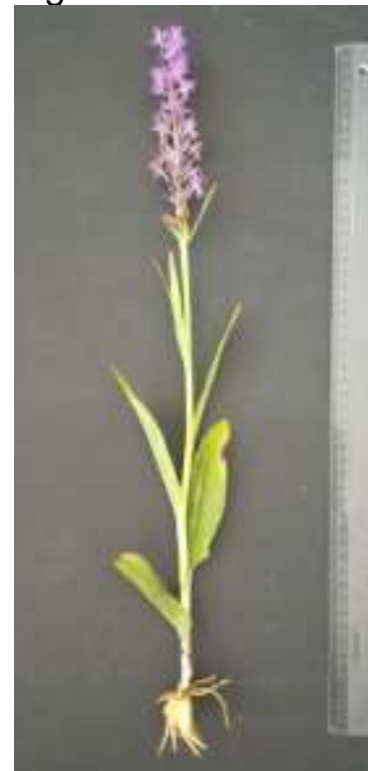

Fifth year 30 June 2019

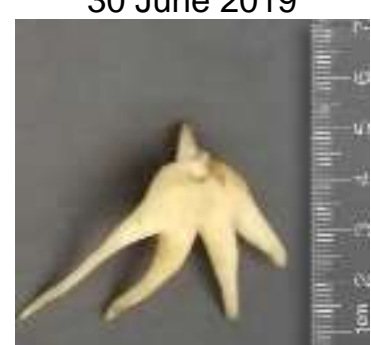

Figure 2. Tuber development according to years.

In the experiment, the plants formed four leaves in the third year. The longest leaf length and leaf width were measured as $13.2 \mathrm{~cm}$ and $2.7 \mathrm{~cm}$, respectively. As it is known, the time to reach flowering maturity is 
called the maturity period and in Dactylorhiza euxina (Nevski) Czerep. species, the maturity period is 3 years. In the third vegetation year, flowering plants reached an average height of $41.7 \mathrm{~cm}$ and produced an average tuber of 0.850 grams. Biomass weight with flowering reached 9.02 grams. In the fourth vegetation period, plant height was $48.8 \mathrm{~cm}$ and biomass weight was 12.41 grams. The largest leaf length in plants with fiveleaf formation was $13.8 \mathrm{~cm}$ and $2.8 \mathrm{~cm}$. The average weight of the new tubers was $1.585 \mathrm{~g}$. In the fifth year, biomass growth continued and was $14.32 \mathrm{~g}$, with an average tuber weight of $2.522 \mathrm{~g}$.

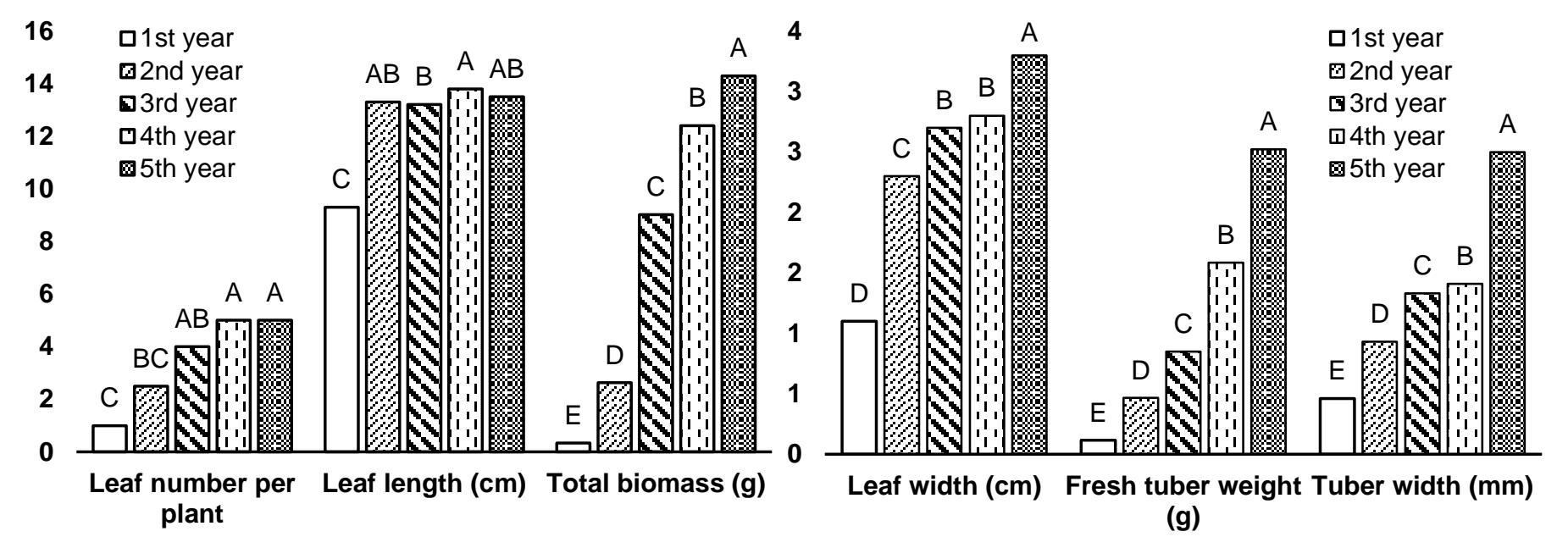

Figure 3. Changes of morphological features according to years.

Although a single salep orchid produces hundreds of thousands of seeds, the chances of survival of the seeds are very low. Seeds that have the chance to germinate in nature complete their development as a tiny plant in the first year. In this study in which the development of Dactylorhiza euxina (Nevski) Czerep. species is followed, it is understood that the plants have a larger structure than the previous year. The findings are the first data presented for the Dactylorhiza euxina (Nevski) Czerep. species.

It is also noteworthy that the size of the tuber increases slightly each year. As long as their genetic capacity allows, this condition continues until the tubers reach a certain size in salep orchids. The main tuber completes its life by producing a slightly larger new tuber. The same tuber development is true for all salep orchids [18]. When the newly formed tubers are planted, they produces bigger tubers than the previous year and completes its vegetation [30]. In other words, each planted tuber continues its generation by creating a slightly bigger tuber than itself $[30,31]$. As a result of the literature survey, there was no study in which the vegetative characteristics of Dactylorhiza euxina (Nevski) Czerep. species were determined. Vegetative characteristics belonging to some other species such as Ophrys lutea, Serapias vomeracea, Ophrys mammosa, Ophrys umbilicata, Orchis sancta, and Dactylorhiza romana of the same family and used as salep orchids have been reported in a small number of studies. These literatures were not included due to the wide variation between the vegetative characteristics described in these studies, which dealt with different genera and species, and the characteristics of the species Dactylorhiza euxina (Nevski) Czerep. The main tuber size controls the morphological characteristics of the species used as the salep orchid. Within the family, Dactylorhiza euxina (Nevski) Czerep. is among the species containing high biomass $[30,31,32,33]$.
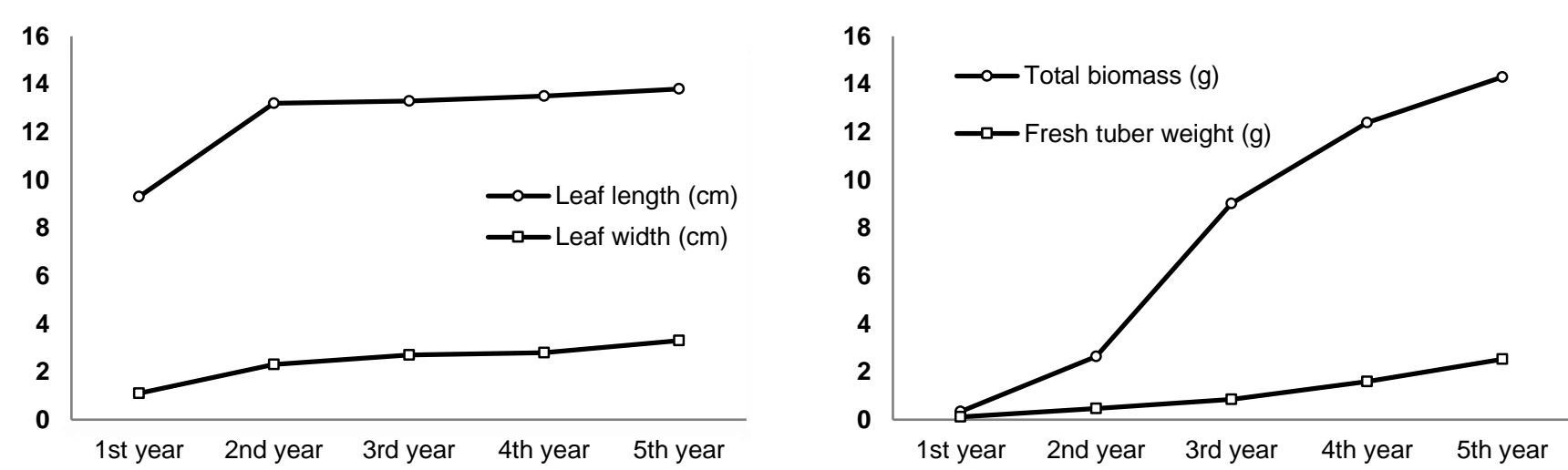

Figure 4. Changes of leaf length, leaf width and fresh tuber weight, total biomass according to years. 
In this study, when the tubers formed in the first year $(0.115 \mathrm{~g})$ were planted, they formed approximately 4 times larger tubers than the average of $0.465 \mathrm{~g}$ tuber weight. In the third vegetation, these tubers produced new tubers at about 2 times their own weight. In the fourth year of the experiment, the tubers gave 1.8 times more bigger new part of tubers. The fifth year tuber was 1.6 times heavier than the fourth year tuber. Total biomass, fresh tuber weight, leaf length and leaf width values are shown in Figure 3 and Figure 4 by years.

As shown in Figures 3 and 4, there is a rapid increase in proportional tuber size in the first years and a slowdown in the rate of increase in the following years. This continues as far as the genetic capacity of the species allows. However, the number of years of genetic capacity reached in terms of tuber weight is unknown in orchids.
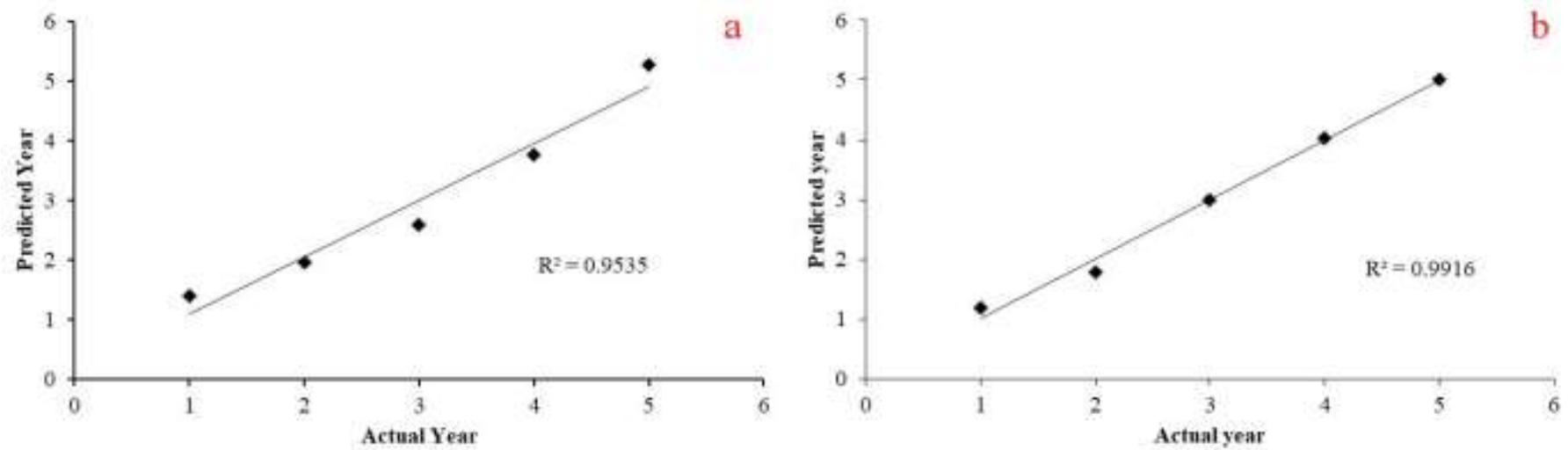

Figure 5. a: Actual and predicted years for fresh tuber weight (g) according to fresh tuber weight. b: Actual and predicted years for fresh tuber weight $(\mathrm{g})$ according to fresh tuber yield and total biomass.

As a result of mathematical modeling, it was found that there was a high correlation between fresh tuber weight, total biomass and plant height. When these relationships are considered as year-fresh tuber weight, year-fresh tuber weight-total biomass and year-fresh tuber weight-total biomass-plant length interactions, accurate estimates are obtained between 95\% and 99\% (Table 2).

A relationship between year $(\mathrm{Y})$ and fresh tuber weight (FTW) was obtained by means of multi-regression analysis and the equation was produced $Y=1.22+(1.61 \times \mathrm{FTW})$. Most of the variation (95\%) in years was explained by the selected parameter, namely fresh tuber weight (Figure $5 \mathrm{a}$ ).

The result of multi-regression analysis showed that there was a significant relationship among year, fresh tuber weight, and total biomass (TBM). As a result of this relationship $Y=1.05+(0.76 \times \mathrm{FTW})+(0.14 \times$ TBM) was obtained (Table 2). It was found that most of the variation (99\%) in year was explained by fresh tuber weight, and total biomass (Figure 5b).
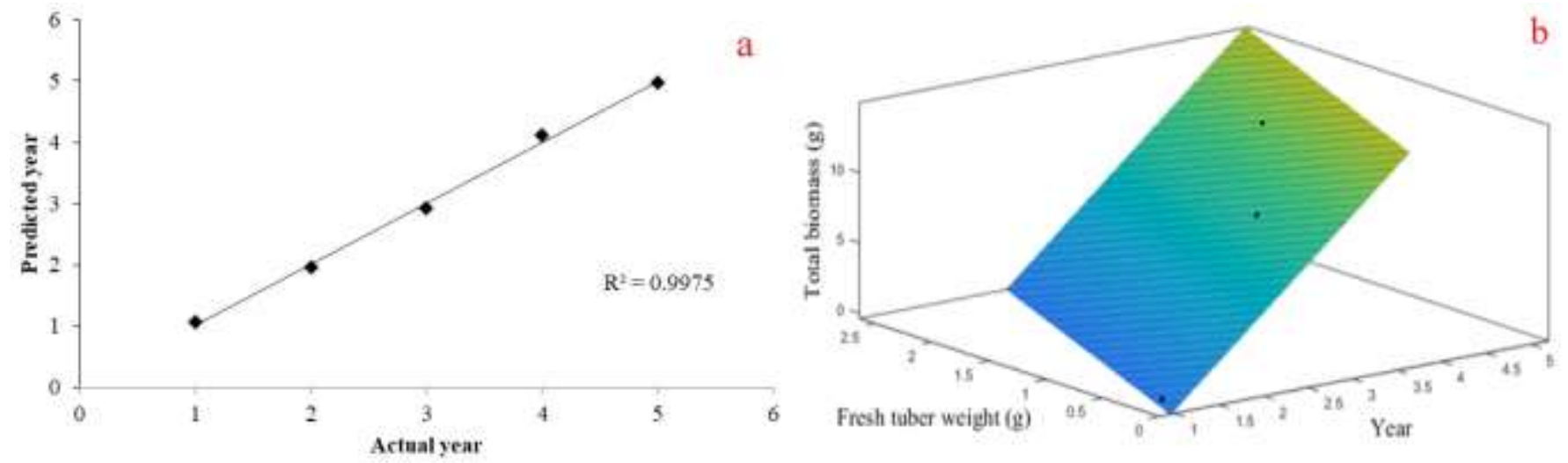

Figure 6. a: Actual and predicted years, according to fresh tuber yield, total biomass, and plant height (cm). b: Interaction of year, fresh tuber yield, total biomass.

Utilising equation $\mathrm{Y}=1.05+(0.76 \times \mathrm{FTW})+(0.14 \times \mathrm{TBM})$, the combined effect of fresh tuber yield, total biomass, and plant height on the year of salep orchid growing was shown in Figure 6a. As seen in Figure 6b, the increase in fresh tuber weight over the years has led to an increase in total biomass. The effect of the years on the increase of total biomass is very high linearly 
Table 2. Statistical analysis for multiple regression. Model 1 is for relationship among the year and fresh tuber weight, model 2 is for relationship among the year, fresh tuber weight, and total biomass, and model 3 is for relationship among the year, fresh tuber weight, total biomass, and plant height.

\begin{tabular}{|c|c|c|c|c|c|c|c|}
\hline Model & $R^{2}$ & $\mathrm{~F}$ & Significance $\mathrm{F}$ & \multicolumn{2}{|c|}{ Coefficients* } & Standard Error & P-value \\
\hline \multirow{2}{*}{1} & \multirow{2}{*}{0.9765} & \multirow{2}{*}{61.5064} & \multirow{2}{*}{0.0043} & $a$ & 1.2206 & 0.2872 & 0.0024 \\
\hline & & & & $b$ & 1.6068 & 0.2049 & 0.0043 \\
\hline \multirow{3}{*}{2} & \multirow{3}{*}{0.9958} & \multirow{3}{*}{117.6346} & \multirow{3}{*}{0.0084} & $a$ & 1.0486 & 0.1603 & 0.0226 \\
\hline & & & & $b$ & 0.7609 & 0.3010 & 0.1273 \\
\hline & & & & c & 0.1433 & 0.0477 & 0.0951 \\
\hline \multirow{4}{*}{3} & \multirow{4}{*}{0.9988} & \multirow{4}{*}{135.6788} & \multirow{4}{*}{0.0063} & $\mathrm{a}$ & 1.7397 & 0.4590 & 0.1642 \\
\hline & & & & $b$ & -0.1104 & 0.6032 & 0.8847 \\
\hline & & & & c & 0.5711 & 0.2763 & 0.2869 \\
\hline & & & & $d$ & -0.0930 & 0.0596 & 0.3625 \\
\hline
\end{tabular}

* $a, b, c$, and d" are coefficients. $a$ is intercept, $b$ is fresh tuber weight, $c$ is total biomass, and d is plant height.

According to the results of multi-regression analysis among year, fresh tuber weight, total biomass, and plant height $(\mathrm{PH})$ was obtained by mean of multi-regression analysis and the equation was produced $\mathrm{Y}=$ $1.74-(0.11 \times \mathrm{FTW})+(0.57 \times \mathrm{TBM})-(0.09 \times \mathrm{PH})$. Most of the variation $(99 \%)$ in years was explained by the selected parameter (Table 2 ).

As a result, the fresh tuber yield of years in the salep orchid and consequently the effect of the plant height and total biomass increase are seen to be important. It is necessary to determine how long the total biomass increase continues depending on the years.

\section{CONCLUSION}

The salep orchids cannot be produced as vegetative and generative. Therefore, they are in danger of extinction. Its collection is prohibited worldwide. Today, however, millions of salep orchids are being collected and used illegally. To date, many researches have focused on the production difficulties of salep orchids. In the literature studies related to the subject, no data is found about the development status by years. This 5year study demonstrates the developmental difficulties of Dactylorhiza euxina (Nevski) Czerep. orchids for the first time in the world. According to the findings, it takes 4-5 years for a germinated Dactylorhiza euxina (Nevski) Czerep. seed to reach a sufficient size. These data make it easier for us to predict the development of other salep orchids.

Funding: This research was funded by the Ondokuz Mayis University, Turkey.

Acknowledgments: I am grateful to Tuba Odabas and Aydan Ermis (Ondokuz Mayis University, School of Foreign Languages) for editing English in this paper. I also thanks Assoc. Prof. Dr. Omer Caliskan and Prof. Dr. Mehmet Serhat Odabas for statistics evaluations and edited the manuscript.

Conflicts of Interest: The authors declare no conflict of interest.

\section{REFERENCES}

1. Arditti J, Ghani AK. Numerical and physical properties of orchid seeds and their biyological implications. The New Phytologist. 2000; 145: 367-421.

2. Bhattarai P, Pandey B, Gautam RK. Chhetri, R. Ecology and conservation status of threatened orchid Dactylorhiza hatagirea (D. Don) Soo. in manaslu conservation area, Central Nepal. American Journal of Plant Science. 2014; 5: 3483-91.

3. Baytop T. Treatment with plants in Turkey (Past and Present). 1st ed., Publiser: Nobel Press, Istanbul, Turkey; 1999.

4. Kasparek M, Grim U. Europen trade in Turkish salep with special reference to Germany. Economic Botany. 1999; 53: 396-406.

5. Sezik E. Turkish orchids and salep. Acta Pharmaceutica Tursica. 2002; 44: 151-7. 
6. Stahlberg D, Hedren M. Systematics and phylogeography of the Dactylorhiza maculata complex (Orchidaceae) in Scandinavia: insights from cytological, morphological and molecular data. Plant Systematics and Evolution. 2008; 273: 107-32.

7. Hossain MM. Therapeutic orchids: traditional uses and recent advances - an overview. Fitoterapia. 2011; 82: 10240.

8. Gorbani A, Gravendeel B, Zarre S, Boer H. Illegal wild collection and international trade of CITES listed terretrial orchid tubers in Iran. Traffic Bulletin. 2014; 26: 53-8.

9. Renz J, Taubenheim G. Orchis L. (Orchidaceae), In Flora of Turkey and the East Aegean Islands Edinburgh, Editor P.H. Davis, Publiser: Edinburgh University Press, United Kingdom, 1984; pp. 451-600.

10. Shipunov AB, Fay MF, Pillon Y, Bateman RM, Chase W. Dactylorhiza (Orchidaceae) in European Russia: combinet moleculer and morphological analysis. American Journal of Botany. 2004; 91: 1419-26.

11. Pedreja SO. Dactylorhiza. In Flora iberica 21 (Smilacaceae-Orchidaceae), XXI ed.; Editor Aedo CA, Herrero A; Publiser: CSIC Press, Madrid, Spain, 2005; pp. 94-111.

12. Daskin R, Yilmaz O, Kaynak G. A new record for the flora of Turkey: Dactylorhiza maculata (L.) Soó (Orchidaceae). Journal of Biological and Environmental Sciences. 2007; 1: 11-4.

13. Xingi C, Gale SW, Cribb PJ, Dactylorhiza Necker ex Nevski. Flora of China. 2009; 25: 114-7.

14. Ernaz EA, Sevgi E, Kara O, Sevgi O, Tecimen HB, Bolat I. Comparative morphological, anatomical and habitat studies on Dactylorhiza romana (Seb.) Soó subsp. romana and Dactylorhiza romana (seb.) Soó subsp. georgica (Klinge) Soó ex Renz \& Taub. (Orchidaceae) in Turkey. Pakistan Journal of Botany. 2012; 44: 143-52.

15. Caliskan O. Salep Orhids, 1st ed.; Publiser: Erol Press, Samsun, Turkey: 2018.

16. Farhoosh R, Riazi A. A compositional study on two currents types of salep in Iran and their reolojical properties as a function of concentration and temperature. Food Hydrocolloids. 2007; 21: 660-66.

17. Blinova IV, Uotila P. Dactylorhiza traunsteineri (Orchidaceae) in Murmanks Region (Russia). Memoranda Societatis pro Fauna et Flora Fennica. 2012; 88: 67-79.

18. Arditti J. Factor affecting the germination of orchid seeds. The Botanical Review. 1967; 33: 1-97.

19. Baskin CC, Baskin JM. Seeds, Ecology, Biogeography, and Evolution of Dormancy and Germination. 1st ed.; Publiser: Academic Press, San Diego, USA; 1998.

20. Cig A, Demirer Durak E, Isler S. In vitro symbiotic germination potentials of some Anacamptis, Dactylorhiza, Orchis and Ophrys terrestrial orchid species. Applied Ecology and Environmental Research. 2018; 16: 5141-55.

21. Rasmussen HN. Terrestrial orchids from seed to mycotrophic plant. 1st ed.; Publiser: Cambridge University Press, Cambridge, UK; 1995.

22. Sezik E, Isler S, Guler N, Orhan C, Aybeke M, Deniz IG, Ustun O. Destruction of orchids and orchids. Tubitak TBAG-Ç.SEK/23 (103T008) Project Final Report, Ankara, Turkey, 2007. Available online: https://trdizin.gov.tr/publication/show/pdf/project/TnpFNU5qWT0 = (accessed on 12 December 2019).

23. Bektas E, Cuce M, Sokmen A. In vitro germination, protocorm formation, and plantlet development of Orchis coriophora (Orchidaceae), a naturally growing orchid species in Turkey. Turkish Journal of Botany. 2013; 37: 33642.

24. Warghat AR, Bajpai PK, Srivastava RB, Chaurasia P, Chauhan RS, Sood H. In vitro protocorm development and mass multiplication of an endangered orchid. Dactylorhiza hatagirea. Turkish Journal of Botany. 2014; 38: 737-46.

25. Sezik E. Our Orchids. 1st ed.; Publiser: Sandoz Culture Press, Izmir, Turkey; 1984.

26. Tutar M, Parlak S, Sarı AO, Cicek F. Seed production in salep orchids. Proceedings of the XI Ecology and Environment Congress, Samsun, Turkey; 2013, pp. 89.

27. Caglayan K, Ozavcı A, Eskalen A. In vitro multiplication of salep orchids, growing commonly in the East Mediterranean region of Turkey by embriyo culture. Turkish Journal of Agriculture and Forestry, 1998; 22: 187-91.

28. Jacobsone G. Morphogenesisi of wild orchid Dactylorhiza fuchsii im tissue culture. Acta Universitatis Latviensis, Biology. 2008; 745: 17-23.

29. Mehra, S. Nutritional and genetic diversity in orchid mycorrhizal fungi from Caladenia species. PhD, RMIT University, Melbourne, Australia; 2014.

30. Caliskan O, Kurt D. Description of development period of Dactylorhiza romana (Sebast.) Soo. during four consecutive years. Anadolu Journal of Agricultural Science. 2019; 34(2):195-200.

31. Caliskan O, Kurt D, Cirak C. Development of new sustainable sahlep production methods using Ophrys sphegodes subsp. mammosa (Desf.) Soo ex E. Nelson. Journal Agricultural Science and Techology. 2019; 21(6): 1547-55.

32. Ertas S, Ozel A, Erden K. Determination of the botanical properties and glucomannan contents of some salep species cultivated in Şanlıurfa conditions. Harran Journal of Agricultural and Food Science. 2019; 23(1): 39-46. 
33. Caliskan O, Kurt D, Odabas MS. Agronomic characteristics of Serapias vomeracea (Burm. f.) Briq. salep orchids. Notulae Botanicae Horti Agrobotanici Cluj-Napoca. 2020; 48(1): 245-60.

2020 by the authors. Submitted for possible open access publication under the terms and conditions of the Creative Commons Attribution (CC BY NC) license (https://creativecommons.org/licenses/by-nc/4.0/). 